\title{
VENDIBLE PROPRIETY OF VEGETABLE GROWERS IN TELANGANA
}

\section{B GOPI CHAND ${ }^{1} \&$ P. K. BANERJEE ${ }^{2}$}

${ }^{I}$ M. Sc. Agriculture, Department of extension Education, Orissa University of Agriculture and Technology Bhubaneswar, India ${ }^{2}$ Associate Professor, Department of extension Education, Orissa University of Agriculture and

Technology Bhubaneswar, India

\begin{abstract}
Marketing of vegetables continuous to be a major constraint faced by the vegetable growers and if the farmers want to be continued in the vegetable production their marketing issues should be addressed. Both purposive and random sampling followed for a total sample size of one hundred and twenty. The findings of the study revealed that majority of the vegetable growers were of middle aged (54.16\%), had high school education (35.88 \%) and belonged to marginal and small farmer's category (32.50\%), low extension participation (80\%), medium risk orientation (65\%) and low innovativeness (14.16\%). The majority of the respondents were growing bitter gourd (37.50\%), packed in gunny bags (57.50\%), sale in wholesale market (33.33\%), transported by auto rickshaw(65.83\%), no storage (86.66\%), below $10 \mathrm{~km}$ of market distance (48.33\%), immediately receiving their payments $(85.83 \%)$ and shown low overall Marketing behavior (56.66\%). Family size, sex, education, experience in vegetable cultivation, social status, size of land holding, extension participation, innovativeness and risk orientation were positively and significantly correlated with overall marketing behavior where as occupation, economic status and social participation was found non-significant with the marketing behavior. Increase in the storage facilities and processing industries will automatically improve contract farming which will reduce their risk and avoid distress sale of vegetables.
\end{abstract}

KEYWORDS: Marketing Behavior, Profile Characteristics, Storage Facilities, Contract Farming \& Distress Sale

Received: Oct 10, 2017; Accepted: Nov 01, 2017; Published: Nov 22, 2017; Paper Id.: IJASRDEC201742

\section{INTRODUCTION}

India is principally a vegetarian country and second largest producer of vegetables (121.02 Million tons), next to China (583.32 Million tons) according to 2013 FAOSTAT Website. Nutrients in the vegetables rich in proteins, carbohydrates, minerals and vitamins indispensable for maintaining good health and overcome disorders, so called as protective foods. Balanced diet, an adult moderately working needs about $300 \mathrm{~g}$ of vegetables per day, as per Dietary Guidelines for Indians, NIN, 2011.

The vegetable marketing system is still at the infant stage of development. Perishable nature of vegetables is an added advantage to the middlemen to exploit the vegetable growers. If the farming community wants to take part in production programs, they must be assured of good prices for their commodities through efficient marketing system. For this farmer-friendly marketing system how a farmer responds to stimuli and how he reacts and interacts in the given situation is important which is disclosed by behavioral studies.

In the light of the above facts the present study was undertaken to investigate various aspects of marketing behavior of vegetable growers with the following objectives. 
- $\quad$ To study the profile of vegetable growers.

- To assess marketing behavior of vegetable growers.

- To analyze the relationship between marketing behavior and selected characteristics of vegetable growers.

\section{METHODOLOGY}

The study was with the farmers from Khammam district of Telangana State. A sample size of 120 was taken with purposive and random sampling procedure, for the study. Ex-post facto research design was followed, using structured interview schedule. Primary source of data was taken from farmers and the secondary source of data, incorporated from journals, thesis, internet and official records of horticulture department. The statistical tools used in the study included frequency, percentage, class interval and Pearson's coefficient of correlation. Twelve farmers each from ten vegetable growing villages selected randomly at the rate of two villages from each of five mandals, comprising a total number of 120 respondents formed the sample for study. After conducting a Pilot study, where discussions with the KVK associates, field level extension officials and district level officials as per the 15 percent of respondents, were personally interviewed for the purpose of pre testing of interview schedule, for its reliability \& validity and after necessary modifications, the final schedule was developed, for eliciting responses from the farmers.

\section{RESULTS AND DISCUSSIONS}

\section{Profile of Vegetable Growers}

Age

Among the vegetable growers, 54.16 percent belonged to middle age, usually farmers of middle age were enthusiastic and having moderate experience in farming and have more work efficiency than younger and older ones.

\section{Gender}

More than three fourth of the population are male (81.67), this might be due to ownership rests with the male where female role who involved from planning to selling had no ownership of the enterprise.

\section{Education}

Little more than one third of the vegetable growers had high school education (35.88 \%), the reason behind it was that farmers believe that getting good school education will help to prosper better in future.

\section{Land holding}

Thirty two point five percent vegetable growers belonged to marginal and small categories; this could be attributed to inheritance of land from their ancestors who might have transferred from generation to generation.

\section{Experience}

A little more than half of the vegetable growers (53.33\%) had less than 10 years of experience even though 65 per cent were middle aged might be due to the fact that farmer's shifts to vegetable cultivation by increased daily demand.

\section{Economic Status}

Nearly half of the vegetable growers $(47.50 \%)$ had a medium economic status, might be their judicious use of 
economic resources, subsidiary occupations undertaken by them and large number of small and medium vegetable growers.

\section{Social Status}

One third of the respondents (33.33\%) belonged to backward caste, this might be due to the medium size of land holding of $\mathrm{BC}$ promote them to grow varied crops to avoid risk.

\section{Social Participation}

Majority of vegetable growers (41.66\%) had no membership in any organization followed by Rythu bazar members (19.16\%), other organizations (18.33\%), Panchayat members (14.16\%), socio-cultural organization (10\%), Religious organizations (4.16\%), School management and Co-operative society (3.33) percent each. No one in the growers was youth club members.

\section{Extension Participation}

Majority $80 \%$ had low extension participation, it may be due to lack of awareness of extension activities conducted in the area and attending other works, which is more important than attending these extension activities.

\section{Achievement Motivation}

Half of the $(50 \%)$ vegetable growers had low achievement motivation might be because, the majority had limited extension contact and social participation.

\section{Innovativeness}

Seventy nine percent respondents were having medium innovativeness quality, may be due to the early majority and late majority categories were more, and government assistance was must to undertake them.

\section{Marketing Behavior of Vegetable Growers}

Table 1: Overall Marketing Behavior of Vegetable Growers

\begin{tabular}{|l|c|c|}
\hline \multicolumn{1}{|c|}{ Category } & F & \% \\
\hline Low Marketing behavior & 68 & 56.66 \\
\hline Medium Marketing behavior & 38 & 31.66 \\
\hline High Marketing behaviour & 14 & 11.66 \\
\hline
\end{tabular}

\section{Type of Vegetables}

Thirty seven point five percent vegetable growers, preferred to grown bitter gourd followed by leafy vegetables (31.66\%), tomato (28.33\%), okra (25.83\%), bottle Gourd (23.33\%), ridge gourd (18.33\%), drum stick (13.33\%), taesel gourd $(10 \%)$ and brinjal $(7.50 \%)$, whereas curry leaf $(1.66 \%)$ is the least preferred to grow. Other vegetable include cabbage/ cauliflower $(4.16 \%)$, green chillies $(3.33 \%)$ and water melon $(3.33 \%)$. The majority of vegetable growers were growing bitter gourd might be, due to the less fluctuations in the prices of bitter gourd comparatively and the leafy vegetable and cucumber second most preferred, as there is high consumption of them.

\section{Reasons for Growing}

Majority (31.66\%) were growing vegetables because of regular income(daily), followed by good market demand 
for vegetables (23.33\%), marketing facilities (16.66\%), government encouragement and assistance (13.33\%), highly remunerative than other crops $(8.33 \%)$ and availability of resources $(6.66 \%)$.

\section{Grading}

Slightly greater than half $(50.83 \%)$ respondents reported to grade their produce, based on one character followed by two characters $(32.50 \%)$ and three characters (10\%) only $6.66 \%$ were not grading their produce. None preferred four or more characters for grading. This shows that, farmers were less aware on how grading of vegetables advantageous in getting good price for the produce. The extension personnel should provide training expertise to improve grading.

\section{Storage}

Majority of 94.16 percent sale their produce daily followed by weekly (4.16\%) and fortnightly (1.66\%). Might be due to need in regular source of income, lack of storage facilities and regular demand in the market propel them to sell daily.

\section{Packing}

More than half (57.50\%) were using gunny bags for packing their produce followed by bamboo basket (20\%), perforated polythene sheets $(18.33 \%)$, wooden box $(14.16 \%)$ and low density polythene films (13.33\%). None preferred high density polythene films as packing material. This might be due to ease in handling and packing of gunny bags for transportation which is followed by bamboo baskets where damage is minimum.

\section{Place of sale}

Majority preferred wholesale market (33.33\%) followed by Rythu bazar (30.83\%), direct selling to the consumer (23.33\%), local market (21.66\%), retailer (10\%), institutional agencies (hostel) and processing industry (3.33\%) each. The majority sell their produce in wholesale market in order to get immediate payment. Only 37 per cent sold their produce in rythu bazar might be, they have to sit all through the day in the market selling their produce. Only, $3 \%$ sold to institutional agencies and none to processing industry, due to lack initiatives like contract farming.

\section{Transport}

Sixty five point eight three percent transported their produce by auto, followed by bicycle (16.66\%), bus (10.83\%), van $(9.16 \%)$ and motor cycle (6.66\%). Respondents never preferred head load and bullock cart, for transporting their produce. The majority preferred auto as their main transport medium, as the flexibility in handling and moving in the village roads, favour farmers to prefer this.

\section{Storage}

Eighty six point six percent of the respondents never stored their produce, followed by traditional storage (10\%) and cold storage $(3.33 \%)$ practice. Most of the marginal and small farmers did not store their produce, due to their poor financial conditions, as they wanted to dispose off their produce at the earliest, in order to clear the debts made during the crop period. Non availability of storage facilities within the village, might be another reason for not storing their produce.

\section{Value Addition}

Nearly, three fourth $(72.50 \%)$ of the vegetable growers were under low value addition category followed by 
medium (23.33\%) and high value addition (4.16\%). Lack of processing and value addition centers is also a reason for low to value addition. Value addition is very important aspect to fetch more prices to their produce. Vegetable growers need to be trained in post- harvest management and need to encourage them to adopt value addition practices.

\section{Distance of Market}

Nearly half (48.33\%) of the vegetable growers performed to below $10 \mathrm{~km}$ distance from the market followed by $10-20 \mathrm{~km}(32.50 \%), 20-30 \mathrm{~km}(10 \%), 30-40 \mathrm{~km}(5 \%), 40-50 \mathrm{~km}(4.16 \%)$ none of the farmers reported to grow vegetable above $50 \mathrm{~km}$ distance from the market for commercial purpose. It may be due to the fact that majority of the vegetable growers preferred to sell at local market because of nearness of market which reduces transportation cost, time and expectation of better price.

\section{Terms \& Conditions for Sale}

Eighty five point eight three per cent of the vegetable growers were immediately receiving their payments for the produce followed by prior payments $(7.50 \%)$ and after sale payment $(6.66 \%)$.

\section{Over all Marketing Behavior}

More than half of vegetable growers exhibited low marketing behavior (56.66\%) followed by 31.66 per cent medium marketing behaviour and high marketing behavior (11.66\%). Majority of the vegetable growers had low marketing behaviour might be due to the fact that low grading, no storage, marginal and small land holding, less awareness on contract farming might be the reasons behind it.

\section{Relationship between Marketing Behavior and Selected Characteristics of Vegetable Growers}

In order to study the nature of relationship between the selected independent variables and dependent variables correlation is employed

\section{Null Hypothesis}

There will be no significant relationship between selected profile characteristics and marketing behaviour of vegetable growers and both of these are independent.

\section{Correlation between Profile Characteristics and Marketing Behavior}

It can be inferred from table that calculated ' $r$ ' values between marketing behaviour and the selected profile characteristics revealed that, in case Family Size, Size of land holding, Extension participation and Innovativeness at 5 percent level of significance was positively and significantly correlated.

Sex, Education, Experience in Vegetable cultivation and Social status (caste) at 1 per cent level of significance were positively and significantly correlated. Hence the null hypothesis rejected in the above two cases. Economic Status was negatively non-significant with the marketing behaviour and Social participation was positively non-significant with the marketing behaviour, hence null hypothesis accepted with regard to these characters.

It can be inferred from table that, calculated ' $r$ ' values between marketing behaviour and the selected profile characteristics revealed that, in case Family Size, Size of land holding, Extension participation and Innovativeness at 5 per cent level of significance was positively and significantly correlated. Sex, Education, Experience in Vegetable cultivation 
and Social status (caste) at 1 per cent level of significance were positively and significantly correlated. Hence, the null hypothesis rejected in the above two cases. Economic Status was negatively non-significant with the marketing behaviour and Social participation was positively non-significant with the marketing behaviour, hence, null hypothesis accepted with regard to these characters.

Age was negatively and significantly correlated with marketing behavior might be due to increase in age innovativeness, achievement motivation and other characters will decline compared to young growers which ultimately decreases the marketing behaviour. Economic status was none significantly correlated with marketing behavior may be due to the higher economic status lead to engagement of third party for marketing their produce. Social participation was nonsignificant with marketing behavior may be due to the time limitation restrict the vegetable growers not to participate in social activities when they involved in marketing and production.

Table 2: Correlation between Marketing Behavior and Profile Characteristics of Vegetable Growers

\begin{tabular}{|l|c|}
\hline \multicolumn{1}{|c|}{ Variables } & $\begin{array}{c}\text { Marketing } \\
\text { Behavior(R Value) }\end{array}$ \\
\hline Age & $\mathbf{- 0 . 1 9 5 *}$ \\
\hline Sex & $\mathbf{0 . 4 9 1 * *}$ \\
\hline Family Size & $\mathbf{0 . 2 1 4 *}$ \\
\hline Education & $\mathbf{0 . 4 7 6 * *}$ \\
\hline Size of land holding & $\mathbf{0 . 3 0 7 *}$ \\
\hline Experience in cultivation & $\mathbf{0 . 4 1 6 * *}$ \\
\hline Economic Status & $\mathbf{- 0 . 0 2 1 N S}$ \\
\hline Social status & $\mathbf{. 2 3 9} * *$ \\
\hline Social participation & $\mathbf{0 0 8 N S}$ \\
\hline Extension participation & $\mathbf{0 . 2 0 6 *}$ \\
\hline Risk orientation & $\mathbf{0 . 4 3 3 * *}$ \\
\hline Innovativeness & $\mathbf{0 . 2 3 4} *$ \\
$* *$ significance at 1 percent & \\
$*$ significance at 5 percent &
\end{tabular}

Farmers with high social status, education, size of land holding, experience in vegetable cultivation, social status, social participation might had more contacts with extension agencies and acquired information on vegetable marketing thereby leading to high marketing behaviour. Innovativeness might help the farmer to keep continuous effort to achieve something.

\section{CONCLUSIONS}

It can be concluded from the study that, increase in the storage facilities and processing industries will automatically improve contract farming which will be helpful in reducing risk and avoiding distress sale. Therefore, overall marketing behavior of the vegetable growers will rise which is very low according to the present study. However, the concerned departments of the government must educate the farmers to use the existing cold storage and also efforts should be made to establish more storage units. There is a need to improve the social participation of vegetable growers for more sharing and establishment of a common platform to market their produce. It is alarming that input agencies are more preferred than government extension agents (AEO/AO), which can be tackled by motivating them to reach the farmers effectively. 


\section{REFERENCES}

1. Gamit, P. S., Khodifad P. B. And Dedun V. S. 2016. Knowledge Of Vegetable Growers About Eco-Friendly Practices, International Journal of Agriculture Sciences, 8(13): 1213-1215.

2. Kappa, K. 2016. Determinants Of Marketed Surplus Of Vegetable Growers In Ranga Reddy District: An Econometric Analysis, Agricultural Situation In India, Directorate Of Economic And Statistics, Department Of Agriculture Cooperation And Farmers Welfare, Ministry Of Agriculture \& Farmers Welfare, Government Of India: 37-42.

3. Kumar, S., Sharma, G., and Yadav, V. K., 2013, Factors Influencing Entrepreneurial Behaviour of Vegetable Growers, Indian Res. J. Ext. Edu.13(1).

4. MadhuShekar, B. R. 2009, Study On Marketing Behaviour Of Chilli Growers In Guntur District Of Andhra Pradesh, M. Sc. (Ag.) Thesis, Acharya N. G. Ranga Agricultural University, Hyderabad.

5. Pawal, R. D., Pisure, B. L., Jamandar, C. R., 2014. Relationship between Socio-economic Characteristics of Brinjal Growers with their Adoption Gap in Production Practices, Trends in Biosciences, 7(19): 2903-2906.

6. Waghmare, M. N. and Shendage, P. N. 2014. Impact of Supermarkets in Retail Marketing of High-value Vegetables,Agricultural Economics Research Review,27: 210. 
